\title{
Role of Nutrients Input Pattern on the Growth Dynamics of Common Freshwater Microalgal Community
}

\author{
Chandrasekharan Nair Aneesh, Ajit Haridas, Vattackatt Balakrishnan Manilal ${ }^{*}$ \\ Process Engineering and Environmental Technology Division, National Institute for Interdisciplinary Science and \\ Technology (NIIST-CSIR), Thiruvananthapuram, India \\ Email: aneeshchandrasekhar@gmail.com, ajitharidas@niist.res.in, ${ }^{*}$ manilalvb@gmail.com
}

Received 28 July 2015; accepted 27 September 2015; published 30 September 2015

Copyright (C) 2015 by authors and Scientific Research Publishing Inc.

This work is licensed under the Creative Commons Attribution International License (CC BY). http://creativecommons.org/licenses/by/4.0/

(c) (i) Open Access

\begin{abstract}
Most of the microalgae present in aquatic systems competed for the same available inorganic nutrients. The successful competitors would eventually dominate the rest because of their adaptive advantageous. Based on this premise, it was important to understand the effect of nutrients input rate on microalgal species-diversity and population. This was investigated in batch experiments of 14 days with pond water samples having natural ecosystem by varying nutrients dosing pattern under natural day light. Nutrients were supplied as single dose and multiple doses to the fresh water microalgal culture of fresh water. Prominent growth of many microalgal species was the key result of multiple dosing of nutrients compared to single or concentrated dosing of nutrients. Simulation towards oligotrophic condition was supporting the diverse population of microalgae. Whereas in the experiments with higher dosing of nutrients in one or two times had dominant growth of two or three microalgae and higher growth of heterotrophic bacteria. This condition resembled the eutrophic or hyper-eutrophic condition of water. This study thus showed the influence of the nutrients supply pattern on the growth and diversity of microalgae in freshwater and the nutrients added on eight, ten and twelve consecutive days from first day were considered as the effective nutrient addition pattern to promote maximum microalgal population present in a freshwater system.
\end{abstract}

\section{Keywords}

Microalgae, Species-Diversity, Eutrophic, Oligotrophic

"Corresponding author.

How to cite this paper: Aneesh, C.N., Haridas, A. and Manilal, V.B. (2015) Role of Nutrients Input Pattern on the Growth Dynamics of Common Freshwater Microalgal Community. American Journal of Plant Sciences, 6, 2481-2491. 


\section{Introduction}

Microalgae occur in all natural waters such as ponds, lakes, rivers and oceans, and are recognized as the primary producers of these ecosystems. The growth of microalgae depends on the changes in environmental parameters particularly temperature, light, nutrients availability and mortality factors such as grazing and parasitism [1] [2] and is regulated by the dynamics of physico-chemical and biotic environments [3]. In short, the dynamics of microalgal growth are governed by the environmental disturbances that can influence species diversity in water bodies.

Among the environmental disturbances in aquatic systems, nutrients additions from various sources by natural and anthropogenic processes have an important role in the microalgal community composition, species diversity and growth. Most of the microalgae compete for the available inorganic nutrients and the successful competitors will eventually dominate the rests [4]. Some reports are available on the theoretical [5] and experimental studies [6] with respect to microalgal competition for nutrients. Different microalgal species possess unequal abilities in the uptake of various nutrients and several species can coexist in a competitive system, if their growth is restricted by nutrients resources. Similarly the potentially limiting resources such as light, nutrients like nitrogen $(\mathrm{N})$, phosphorous $(\mathrm{P})$, silicon $(\mathrm{Si})$ and trace elements have been the subject of detailed studies with respect to microalgal diversity and biomass production [7]-[9]. The effect of pulsed inflow of phosphate has been experimented in lake water and result of the study shows enhancement of coexisting microalgal species [10]. Related studies show that grazing by zooplankton can disguise the true effects of nutrients loading rate on microalgal species diversity and population [11] [12]. Also it can act as a driving force to select and dominate certain type of microalgae in the community. Hence, the input rate of nutrients to aquatic system may change the microalgal growth and diversity to some extent.

However, the impact of nutrients supply in varied pattern on the growth of microalgae, population and species diversity under natural daylight is yet to be revealed clearly. Information in this aspect will be useful for promoting the growth of natural spectra of microalgae in aquaculture system. Current study demonstrates the growth of individual species of microalgae in pond water with varied pattern of nutrients supply. The results are discussed to find out the role of nutrients supply pattern on species diversity and population.

\section{Materials and Methods}

\subsection{Sampling Site and Collection}

The present investigation was carried out with fresh water sample collected from Padmatheertha pond maintained by Padmanabha Swami Temple Trust, located at the latitude N8 $28^{\prime} 59.8299^{\prime \prime}$ and longitude E76 $56^{\circ} 44.7432^{\prime \prime}$ in Thiruvananthapuram city, Kerala, India. Temperature and $\mathrm{pH}$ of the water were measured at the sampling site using a calibrated Celsius thermometer and transportable $\mathrm{pH}$ meter by the method of Bakes model [13]. Samples collected were maintained at the temperature between $5^{\circ} \mathrm{C}-7^{\circ} \mathrm{C}$ and brought to the laboratory within 30 minutes for further studies.

\subsection{Physico-Chemical and Biological Analysis}

Dissolved oxygen was determined by following Winkler's method [14]. Residual ammonia and phosphate was measured using UV visible spectrophotometer [14]. Suspended solids in the samples were estimated as per the method of Bakes [14], and expressed as biomass concentration. Identification of the microalgae was done by morphological characteristics as illustrated in the previous literature [15] [16]. Enumeration of the microalgae was done using a Sedgwick-Rafter counting chamber. Enumeration of total heterotrophic bacteria was done by acridine orange direct count method described by Hobbie et al. [17]. The methods used for the enumeration of both microalgae and heterotrophic bacteria do not distinguish between viable and non-viable cells.

\subsection{Experimental Details}

The pond water samples of $1 \mathrm{~L}$ each was taken in seven sets of transparent plastic conical flasks having capacity of $2 \mathrm{~L}$. The experimental flasks were kept on magnetic stirrers for gentle mixing under sunlight. Nutrients solution supplied in the experiments had $\mathrm{NH}_{4} \mathrm{Cl}-0.1 \mathrm{~g}$ (a final concentration of $\mathrm{NH}_{3}-31.8 \mathrm{mg} / \mathrm{L}$ ), $\mathrm{KH}_{2} \mathrm{PO}_{4}-0.025$ $\mathrm{g}$ (a final concentration of $\mathrm{PO}_{4}^{3-}-17.4 \mathrm{mg} / \mathrm{L}$ ), micronutrients $-1.5 \mathrm{~mL}$ (from a stock solution of $1000 \mathrm{ml}$ having 
Table 2. Physical and chemical characteristics of Padmatheertha pond water in Thiruvananthapuram city, India.

\begin{tabular}{cc}
\hline Analytical Parameters & Measured Value \\
\hline $\mathrm{pH}$ & 8.3 \\
Dissolved Oxygen $(\mathrm{mg} / \mathrm{L})$ & 7.6 \\
TSS (mg/L) & 25 \\
Ammoniacal Nitrogen (mg/L) & 0.26 \\
Phosphate (mg/L) & 0.03 \\
Chlorophyll $a\left(\mathrm{mg} / \mathrm{m}^{3}\right)$ & 1.8 \\
\hline
\end{tabular}

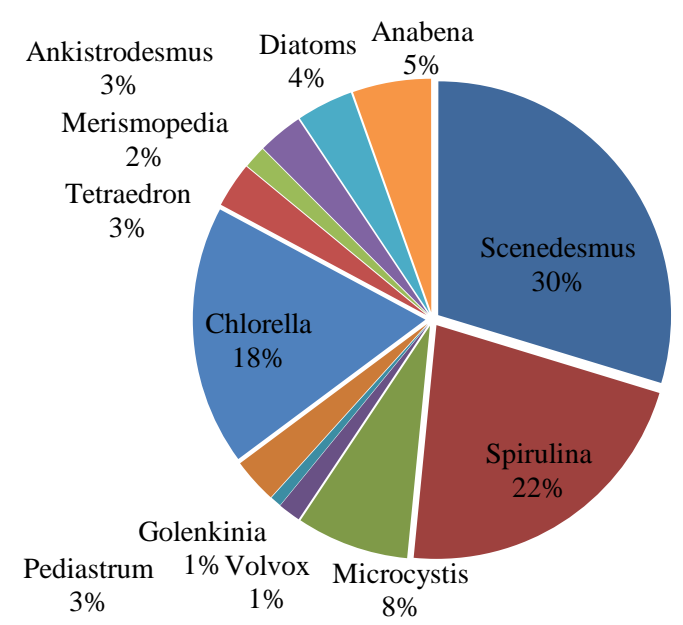

Figure 1. Microalgal distribution pattern of Padmatheertha pond water in Thiruvananthapuram city, India.

\subsection{Influence of Nutrients Input Pattern on Microalgal Growth, Diversity and Population}

In the water sample collected from Padmatheertha pond, Scenedesmus, Spirulina and Chlorella were the dominant microalgae in the community, but Microcystis also had a prominence with its total population of 8\% (Figure 1). When the nutrients were added in a single dose, Scenedesmus became the dominant microalgae throughout the experimental period and diatoms were the second largest. The growth of Spirulina and Chlorella were declined from the initial level with this one-time addition of nutrients. The population of certain species such as Volvox, Pediastrum, Tetraedron, Merismopedia and Anabena were decreased significantly or vanished from the initial level under this experimental condition. Closterium and Micractinium were not observed during the first day of the experiment, but began to appear in the system during the experiment period (Figure 2).

The supply of nutrients distributed in two successive days was resulted in the dominant growth of Scenedesmus followed by diatoms (Figure 3), however, the total number of Scenedesmus was lesser in the system compared to the starting day. The growth of Chlorella and Spirulina was found decreasing from the initial population. Exceptionally, Microcystis population rose to 3000 cells/mL on the second day, but from fourth day onwards it was started decreasing, and on the final day the count was recorded as 250 cells $/ \mathrm{mL}$. The initially absent Closterium and Micractinium were appeared in the system during the experiment period.

Leading growth of Scenedesmus and diatoms was continued as significant on the supply of nutrients in four days consecutively, and observed that the population of diatom was larger than the Scenedesmus towards the end of the experiment. The growth of Chlorella and Spirulina were observed decreasing from the first day (Figure 4).

While supplying the nutrients to six equal doses, a steady increase of growth was observed for Scenedesmus, 
Chlorella, diatoms and for Ankistrodesmus unlike nutrients supplied in one or two doses. The growth of Spirulina was in the decreasing trend throughout the period of experiment. Certain species like Merismopedia, Anabena and Volvox were not found in the experimental system after two days (Figure 5).

When the nutrients were divided and supplied in eight consecutive days, six microalgae namely Scenedesmus, Spirulina, Pediastrum, Chlorella, diatoms and Ankistrodesmus were found dominating in the community. In this experimental system the growth of Microcystis was not altered much during the experimental period, however, Volvox, Golenkinia, Merismopedia and Anabena were disappeared during the period (Figure 6).

Prominent growth of Scenedesmus, Spirulina, Pediastrum, Chlorella, Closterium, Microcystis, Ankistrodesmus, diatoms and Micractinium was observed when the supply of nutrients in ten consecutive days. Volvox was continuously absent in this system like in previous cases (Figure 7).

By the supply of nutrients in twelve days, the originally present microalgae, Scenedesmus, Spirulina, Microcystis, Pediastrum, Chlorella, Closterium, Ankistrodesmus and diatoms were grown in more or less similar proportion, except Volvox, Closterium, Anabena and Micractinium (Figure 8).

Initial level of supplied nutrients and its residual concentration after the experiment were measured and are given in Table 3. In all the experimental flasks, residual concentration of ammoniacal nitrogen was fairly higher than the supplied concentration.

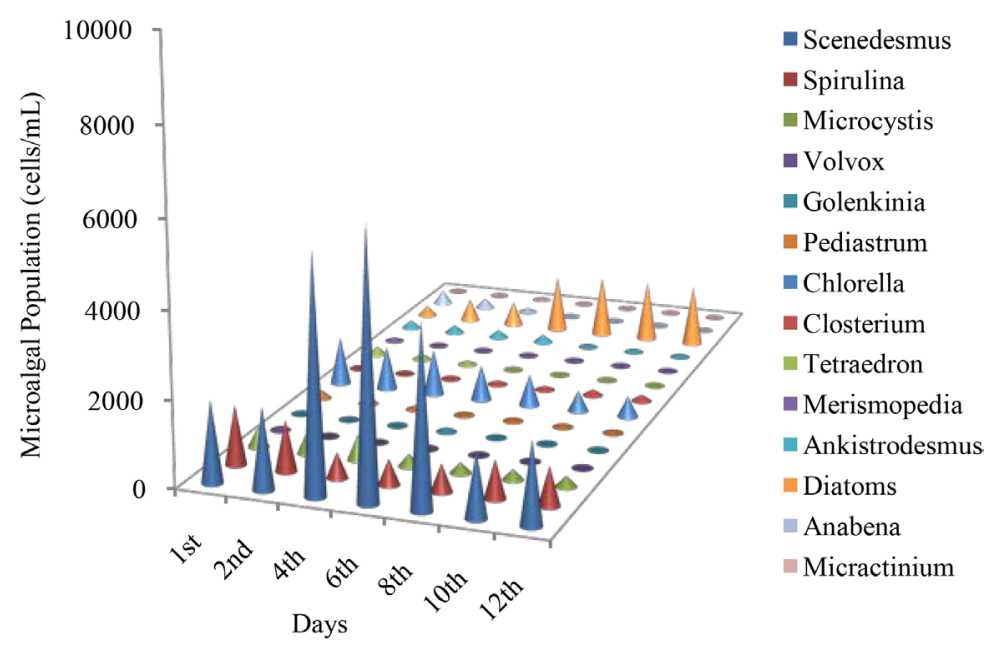

Figure 2. Account of microalgal population by supplying nutrients in a single dose on day one.

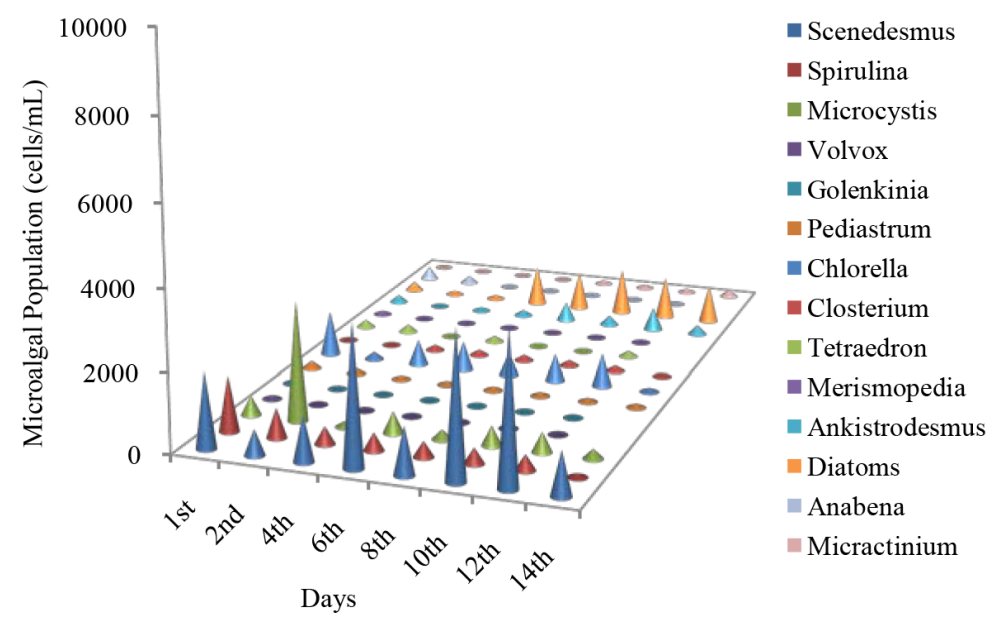

Figure 3. Account of microalgal population by dividing and evenly supplying nutrients on two consecutive days from day one. 


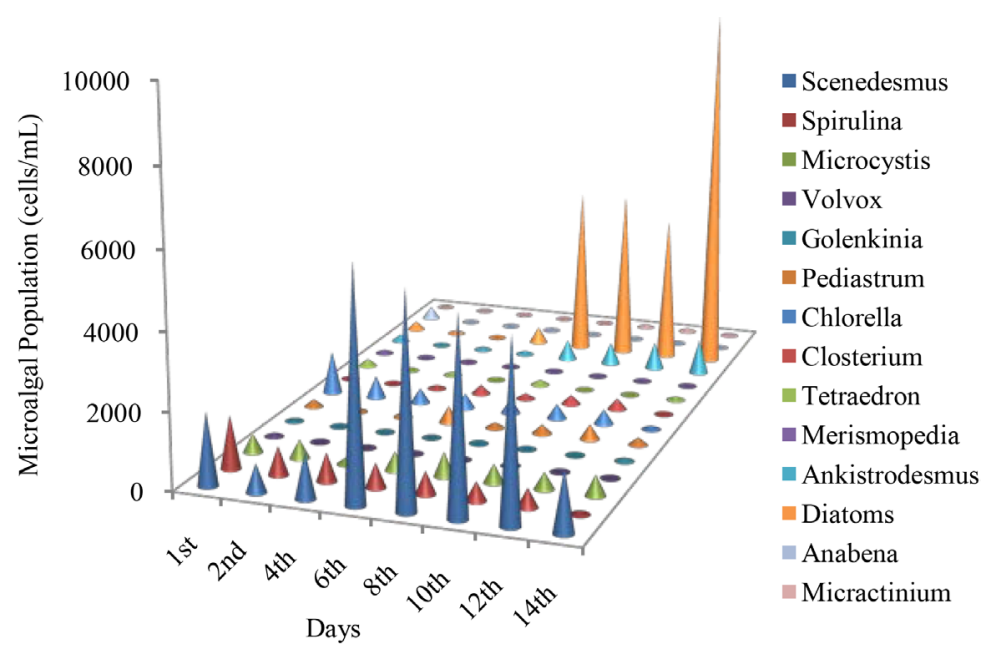

Figure 4. Account of microalgal population by dividing and evenly supplying nutrients on four consecutive days from day one.

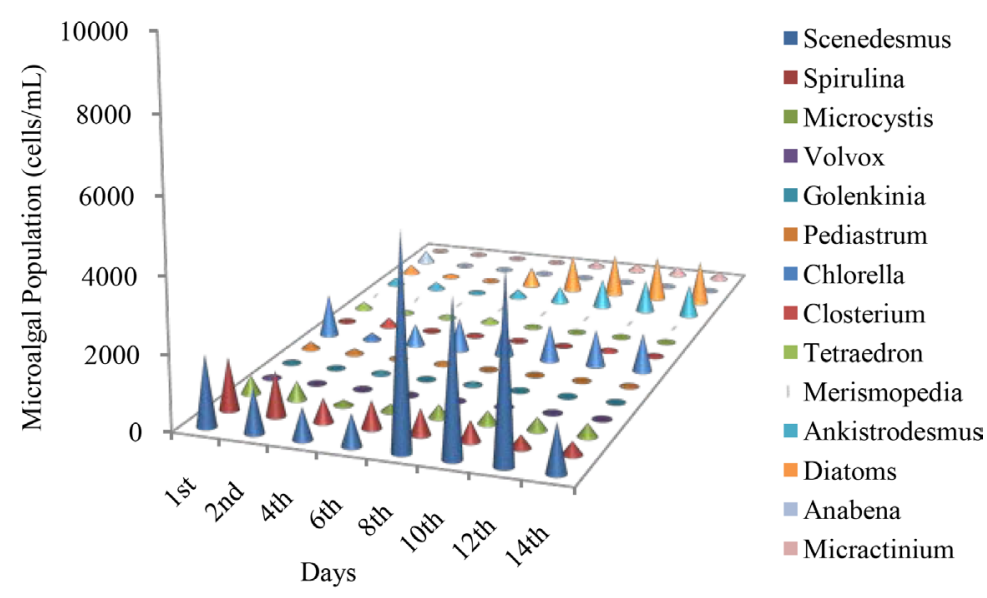

Figure 5. Account of microalgal population by dividing and evenly supplying nutrients on six consecutive days from day one.

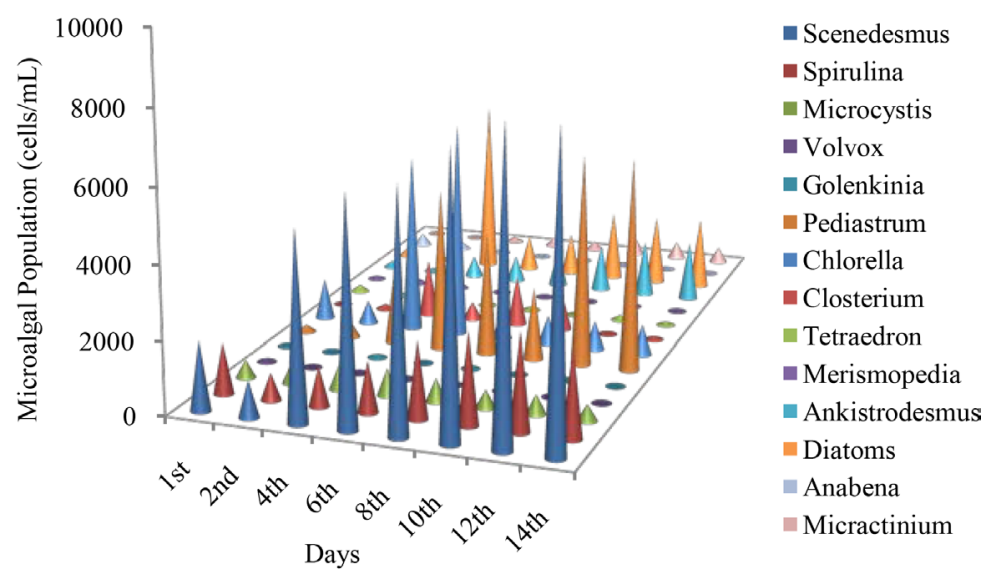

Figure 6. Account of microalgal population by dividing and evenly supplying nutrients on eight consecutive days from day-one. 


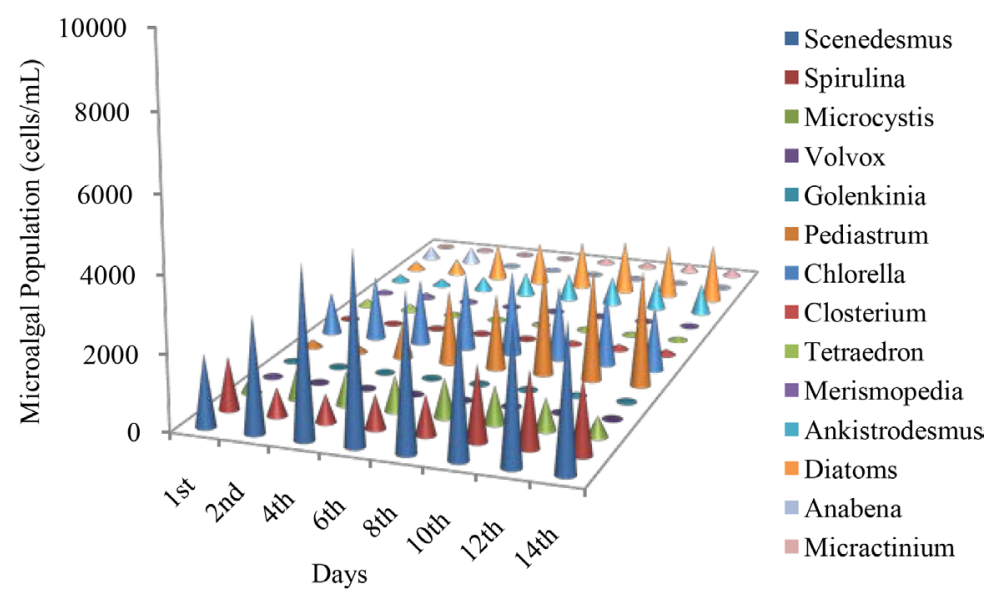

Figure 7. Account of microalgal population by dividing and evenly supplying nutrients on ten consecutive days from day one.
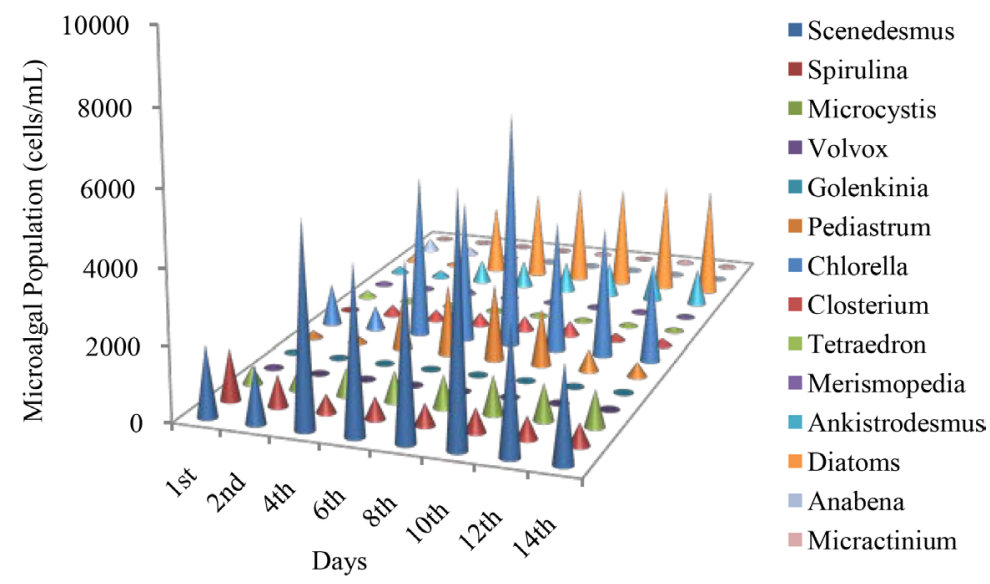

Figure 8. Account of microalgal population by dividing and evenly supplying nutrients on twelve consecutive days from day one.

Table 3. Content of ammonia and phosphate in the beginning and at the end of the experiment.

\begin{tabular}{|ccccc}
\hline & \multicolumn{2}{c}{ Ammoniacal Nitrogen } & Phosphate \\
\cline { 2 - 5 } Nutrients Supply Pattern & $\begin{array}{c}\text { Calculated Value Based } \\
\text { on the Supplied } \\
\text { Nitrogen (mg/L) }\end{array}$ & $\begin{array}{c}\text { Final Concentration } \\
\text { Obtained during } \\
\text { the End of the } \\
\text { Experiment }(\mathrm{mg} / \mathrm{L})\end{array}$ & $\begin{array}{c}\text { Calculated Value Based } \\
\text { on the Supplied } \\
\text { Phosphorus (mg/L) }\end{array}$ & $\begin{array}{c}\text { Final Concentration } \\
\text { Obtained during } \\
\text { the End of the } \\
\text { Experiment (mg/L) }\end{array}$ \\
\hline Single Dose on First Day & 31.8 & 83.85 & 17.4 & 12.3 \\
Two Consecutive Days & 31.8 & 46.45 & 17.4 & 5.6 \\
Four Consecutive Days & 31.8 & 50.7 & 17.4 & 5.5 \\
Six Consecutive Days & 31.8 & 58.4 & 17.4 & 7.95 \\
Eight Consecutive Days & 31.8 & 59.35 & 17.4 & 12.55 \\
Ten Consecutive Days & 31.8 & 37.1 & 17.4 & 5.5 \\
Twelve Consecutive Days & 31.8 & 38.3 & 17.4 & 6.05 \\
\hline
\end{tabular}




\subsection{Growth of Heterotrophic Bacteria with Respect to Microalgal Growth on Varied Supply Pattern of Nutrients}

Increased heterotrophic bacterial growth to the level of $7 \times 10^{5}$ cells $/ \mathrm{mL}$ from $2 \times 10^{3}$ cells $/ \mathrm{mL}$ was observed with the supply of nutrients in a single dose (Figure 9). However, growth of bacteria after the highest record on the 6th day was declined further. The same trend of bacterial growth was observed in the experiment where nutrients supplied in multiple doses, but the maximum population obtained was only $2 \times 10^{4}$ cells/mL (Figure 10).

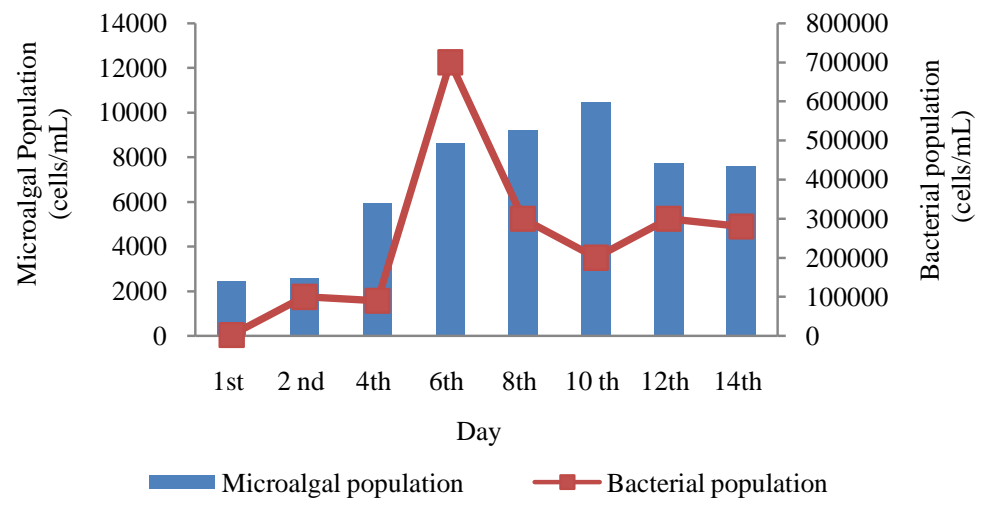

Figure 9. Account of total microalgal and bacterial population with the supply of nutrients in a single dose on day-one.

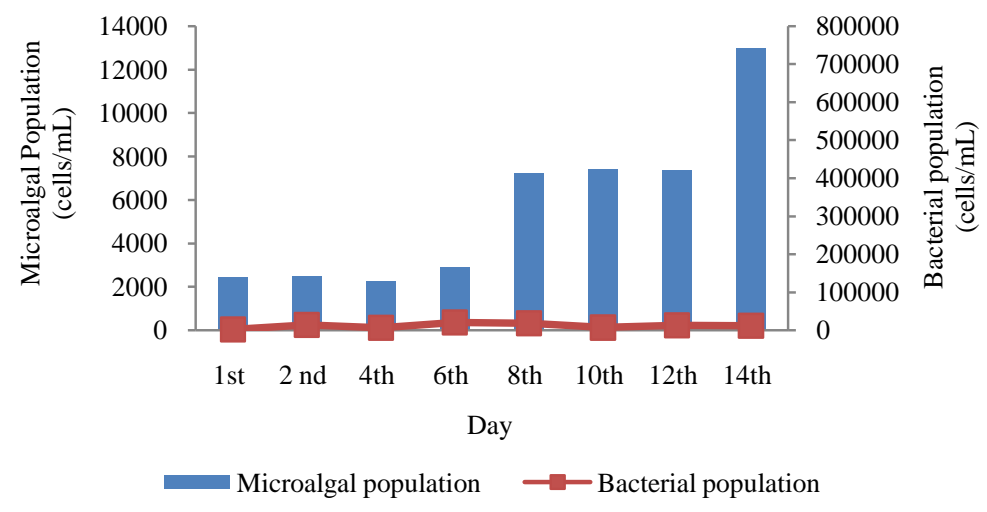

Figure 10. Account of total microalgal and bacterial population with the supply of nutrients on six consecutive days from day-one.

\section{Discussion}

A noticeable change in the growth and population of microalgae was the key result of the experiment to supply the nutrients in varied pattern. The domination of only two microalgae, Scenedesmus and diatoms was observed by the supply of nutrients in a single dose and similar trend was followed when nutrients were added within two and four consecutive days. While distributed supply of nutrients for six, eight, ten and twelve consecutive days was resulted in the prominent growth of many microalgae likes Spirulina, Microcystis, Pediastrum, Chlorella, Closterium, Ankistrodesmus, in addition to Scenedesmus and diatoms. All of them were found growing in more or less same ratio. With some exceptions, results of the experiments generally supported the view that nutrients input pattern influences the individual population of microalgae significantly. The change in individual population with respect to the nutrients input pattern can be explained as follows reasonably.

The nutrients are essential for the growth and primary production of microalgae or phytoplankton in general [19] [20]. Quantitative input pattern of nutrients determines the eutrophic and oligotrophic nature of aquatic systems [21] [22], which in turn have an effect on the diversity and population of microalgae [23] [24]. Excess nutrients such as nitrogen and phosphorous in water bodies lead to eutrophication that causes major shift in the 
community structure of microalgae by falling the biodiversity [25]. On the contrary, in oligotrophic waters with low nutrients input microalgal species are mainly dependent on recycled nutrients [26] and this may not favour the luxuriant of only few species. In such eutrophic systems competition for available light and space are mainly utilized by the dominant species and rests are suppressed. Such a condition would not likely to exist in oligotrophic waters where every organisms can get a share of the ecological condition particularly space and light. Thus the microalgal community structure gradually shifts from abundance of many species to dominance of relatively few species, with the nutrients gradient from oligotrophic to eutrophic environment. The initial aquatic members are certainly the base for the growth and diversity.

In this study supply of nutrients in a single dose appears to resemble the eutrophied state of an aquatic system which was resulted in the domination and abundance of mainly two microalgae such as Scenedesmus and diatoms. Obviously the Scenedesmus and diatoms are two ubiquitous common fresh water microalgae, which are known for their fast growth rate and nutrients uptake [27]. Therefore introduction of a massive concentration of nutrients favours fast growing organisms [28] which could absorb nutrients faster and other organisms may have lesser chances for getting nutrients before it is exhausted. More or less similar growth of microalgae was observed during the supply of nutrients within two and four days, which is again supporting the condition of eutrophication. Usually fast growing organisms have poor ability to sequester nutrients under nutrient limited conditions than slow growing organisms [29] [30].

While the nutrients were supplied in distribution like six, eight, ten and twelve days there were the dominant growth of eight different microalgal species. In this case the overgrowth of few species is not supported with nutrients input and cannot outcompete for nutrients. This study shows that the condition of water towards oligotrophism could favour greater species diversity in nature.

The growth of heterotrophic bacteria with higher input of inorganic nutrients was significantly greater than the lower and distributed supply dosing (Figure 9 \& Figure 10). It is also observed that the concentrated dosing of nutrients supported the growth of bacteria than the majority of microalgae. There could be a competition between microalgae and bacteria for the inorganic nutrients in the system [31] [32], where the distributed and lower level input favoured the growth of microalgae in general. Under eutrophic condition the bacterial growth is also found to be promoted like selected microalgae. By the dominance of few microalgae and heterotrophic bacteria several microalgae become dormant or disappear from the water body. The considerable difference in growth of heterotrophic bacteria between concentrated and distributed dosing indicates the active consumption of inorganic nutrients by heterotrophic bacteria which in turn out-compete microalgal species in the system.

\section{Conclusion}

Nutrients are supplied to the culture within one day, two days and four days has an eutrophic effect on microalgal ecosystem where growth is limited to few fast growers such as Scenedesmus and diatoms. Supply of nutrients by distributing eight, ten and twelve consecutive days promotes the growth of many species of microalgae as in oligotrophic waters. In addition to the growth of few microalgae higher dosing of nutrients prompts heterotrophic bacterial growth to more than hundred times compare to the growth of lower supply of nutrients. Inter relations of nutrients level, heterotrophic bacterial growth and microalgal ecosystem are difficult to explain with this study, which require further investigations. Confirmation of the findings is however, recommended through onsite studies.

\section{References}

[1] Padisák, J. and Dokulil, M. (1994) Meroplankton Dynamics in a Saline, Turbulent, Turbid Shallow Lake (Neusiedlersee, Austria and Hungary). Phytoplankton in Turbid Environments: Rivers and Shallow Lakes. Springer, Springer Science and Business Media, 23-42.

[2] Sommer, U. (1995) An Experimental Test of the Intermediate Disturbance Hypothesis Using Cultures of Marine Phytoplankton. Limnology and Oceanography, 40, 1271-1277. http://dx.doi.org/10.4319/lo.1995.40.7.1271

[3] Wetzel, R.G. (1983) Attached Algal-Substrata Interactions: Fact or Myth, and When and How? Vol. 17, In: Wetzel, R., Ed., Periphyton of Freshwater Ecosystems, Springer, Netherlands, 207-215. http://dx.doi.org/10.1007/978-94-009-7293-3_28

[4] Hutchinson, G.E. (1953) The Concept of Pattern in Ecology. Proceedings of the Academy of Natural Sciences of Philadelphia, 1-12. 
[5] Peterson, D.H., Conomos, T.J., Broenkow, W.W. and Scrivani, E.P. (1975) Processes Controlling the Dissolved Silica Distribution in San Francisco Bay. Estuarine Research, 1, 153-187.

[6] Tilman, D. (1977) Resource Competition between Plankton Algae: An Experimental and Theoretical Approach. Ecology, 58, 338-348. http://dx.doi.org/10.2307/1935608

[7] Sommer, U. (1984) The Paradox of the Plankton: Fluctuations of Phosphorus Availability Maintain Diversity of Phytoplankton in Flow-Through Cultures. Limnology and Oceanography, 29, 633-636. http://dx.doi.org/10.4319/10.1984.29.3.0633

[8] Gaedeke, A. and Sommer, U. (1986) The Influence of the Frequency of Periodic Disturbances on the Maintenance of Phytoplankton Diversity. Oecologia, 71, 25-28. http://dx.doi.org/10.1007/BF00377315

[9] Barbiero, R.P., James, W.F. and Barko, J.W. (1999) The Effects of Disturbance Events on Phytoplankton Community Structure in a Small Temperate Reservoir. Freshwater Biology, 42, 503-512. http://dx.doi.org/10.1046/j.1365-2427.1999.00491.x

[10] Sommer, U. (1983) Nutrient Competition between Phytoplankton Species in Multispecies Chemostat Experiments. Archiv für hydrobiology, 96, 399-416.

[11] Reynolds, C.S. (1984) The Ecology of Freshwater Phytoplankton. Cambridge University Press, Cambridge.

[12] Reynolds, C.S. (1989) Physical Determinants of Phytoplankton Succession. In: Sommer, U., Ed., Plankton Ecology, Springer-Verlag, Berlin, 9-56. http://dx.doi.org/10.1007/978-3-642-74890-5_2

[13] Bakes, R.G. (1978) Concept and Determination of pH. Vol. 1, In: Kolthoff, I.M. and Elving, P.J., Eds., Treatise on Analytical Chemistry, Wiley Interscience, New York, 812.

[14] APHA (1998) Standard Methods for the Examination of Water and Wastewater. 20th Edition, American Public Health Association, New York.

[15] Palmer, C.M. (1980) Algae and Water Pollution: The Identification, Significance, and Control of Algae in Water Supplies and in Polluted Water. Castle House Publications, Los Angeles.

[16] Hobbie, J.E., Daley, R.J. and Jasper, S. (1977) Use of Nuclepore Filters for Counting Bacteria by Fluorescence Microscopy. Applied and Environmental Microbiology, 33, 1225-1228.

[17] Reynolds, C.S. (1980) Phytoplankton Assemblages and Their Periodicity in Stratifying Lake Systems. Ecography, 3, 141-159. http://dx.doi.org/10.1111/j.1600-0587.1980.tb00721.x

[18] Ho, T.-Y., Quigg, A., Finkel, Z.V., Milligan, A.J., Wyman, K., Falkowski, P.G. and Morel, F.M.M. (2003) The Elemental Composition of Some Marine Phytoplankton. Journal of Phycology, 39, 1145-1159. http://dx.doi.org/10.1111/j.0022-3646.2003.03-090.x

[19] Allen, M.B. and Arnon, D.I. (1955) Studies on Nitrogen-Fixing Blue-Green Algae. I. Growth and Nitrogen Fixation by Anabaena cylindrica Lemm. Plant Physiology, 30, 366-372. http://dx.doi.org/10.1104/pp.30.4.366

[20] Biller, P., Ross, A.B., Skill, S., Lea-Langton, A., Balasundaram, B., Hall, C., Riley, R. and Llewellyn, C. (2012) Nutrient Recycling of Aqueous Phase for Microalgae Cultivation from the Hydrothermal Liquefaction Process. Algal Research, 1, 70-76. http://dx.doi.org/10.1016/j.algal.2012.02.002

[21] Smith, G.D. and Doan, N.T. (1999) Cyanobacterial Metabolites with Bioactivity against Photosynthesis in Cyanobacteria, Algae and Higher Plants. Journal of Applied Phycology, 11, 337-344. http://dx.doi.org/10.1023/A:1008115818348

[22] Hilton, J., O’Hare, M., Bowes, M.J. and Jones, J.I. (2006) How Green Is My River? A New Paradigm of Eutrophication in Rivers. Science of the Total Environment, 365, 66-83. http://dx.doi.org/10.1016/j.scitotenv.2006.02.055

[23] Worm, B., Lotze, H.K., Hillebrand, H. and Sommer, U. (2002) Consumer versus Resource Control of Species Diversity and Ecosystem Functioning. Nature, 417, 848-851. http://dx.doi.org/10.1038/nature00830

[24] White, E.M., Vaughan, P.P. and Zepp, R.G. (2003) Role of the Photo-Fenton Reaction in the Production of Hydroxyl Radicals and Photobleaching of Colored Dissolved Organic Matter in a Coastal River of the Southeastern United States. Aquatic Sciences, 65, 402-414. http://dx.doi.org/10.1007/s00027-003-0675-4

[25] Moss, B. (1973) Diversity in Fresh-Water Phytoplankton. American Midland Naturalist, 90, 341-355. http://dx.doi.org/10.2307/2424458

[26] Villareal, T.A., Pilskaln, C.H., Montoya, J.P. and Dennett, M. (2014) Upward Nitrate Transport by Phytoplankton in Oceanic Waters: Balancing Nutrient Budgets in Oligotrophic Seas. Peer J, 2, e302. http://dx.doi.org/10.7717/peerj.302

[27] Borowitzka, M. and Borowitzka, L. (1988) Limits to Growth and Carotenogenesis in Laboratory and Large-Scale Outdoor Cultures of Dunaliella salina. In: Stadler, T., Mollion, J., Verdus, M.-C, Karamanos, Y., Morvan, H. and Christiaen, D., Eds., Algal Biotechnology, Elsevier Applied Science, Essex, 371-381.

[28] Bokn, T.L., Moy, F.E., Christie, H., Engelbert, S., Karez, R., Kersting, K., Kraufvelin, P., Lindblad, C., Marba, N. and 
Pedersen, M.F. (2002) Are Rocky Shore Ecosystems Affected by Nutrient-Enriched Seawater? Some Preliminary Results from a Mesocosm Experiment. In: Vadstein, O. and Olsen, Y., Eds., Sustainable Increase of Marine Harvesting: Fundamental Mechanisms and New Concepts, Springer, Amsterdam, 167-175. http://dx.doi.org/10.1007/978-94-017-3190-4_14

[29] Pedersen, M.F. and Hansen, P.J. (2003) Effects of High pH on the Growth and Survival of Six Marine Heterotrophic Protists. Marine Ecology Progress Series, 260, 33-41. http://dx.doi.org/10.3354/meps260033

[30] Egge, J. (1998) Are Diatoms Poor Competitors at Low Phosphate Concentrations? Journal of Marine Systems, 16, 191198. http://dx.doi.org/10.1016/S0924-7963(97)00113-9

[31] Rier, S.T. and Stevenson, R.J. (2002) Effects of Light, Dissolved Organic Carbon, and Inorganic Nutrients [2pt] on the Relationship between Algae and Heterotrophic Bacteria in Stream Periphyton. Hydrobiologia, 489, 179-184. http://dx.doi.org/10.1023/A:1023284821485

[32] Qu, L., Wang, R.J., Zhao, P., Chen, R.N., Zhou, W.L., Tang, L.Q. and Tang, X.X. (2014) Interaction between Chlorella vulgaris and Bacteria: Interference and Resource Competition. Acta Oceanologica Sinica, 33, 135-140. http://dx.doi.org/10.1007/s13131-014-0432-7 